\title{
CHEMICAL HAZARDS IN PHARMACEUTICAL INDUSTRY: AN OVERVIEW
}

\author{
PRINCY AGARWAL*, ANJU GOYAL, RAJAT VAISHNAV
}

Department of Quality Assurance, Bhupal Nobles Institute of Pharmaceutical Sciences, Sevashram Road, Udaipur, Rajasthan, India. Email: princyagarwal2992@gmail.com

Received: 17 October 2017, Revised and Accepted: 14 November 2017

ABSTRACT

The pharmaceutical industry is a vital component of health-care systems all over the world engaged in discovery, development, manufacture, and marketing of medicines for human as well as animal health. Pharmaceutical industries also have many environmental problems, like the other chemical industries. The pharmaceutical industry is based primarily on the scientific formulation, research, and development of drugs, that is, helpful in the prevention or treatment of diseases and disorders. The manufacturing of APIs and formulation processes involves the use of various chemicals which includes various corrosive and irritant agents such as acids, bases, oxidizing and reducing agents, solvents, and many more which can be found sometimes at very high concentrations and are hazardous to health of persons performing the various processes during manufacturing and formulation of API and medicines. The effective management of the chemical risks linked to the handling of these agents is mandatory for the safety of the workers in the industry, ethically and also legally as per the rules and guidelines of various acts regulating the functioning of the pharma industry. This article provides a comprehensive review of various chemical hazards generally encountered by the pharmaceutical industry, its management and regulation in India.

Keywords: Chemical hazards, Industrial hazard, Organic solvent, Hazardous gases, Organic synthesis, Management of hazard, Regulations for chemical hazard, Regulatory agencies for hazards, Workplace safety, Threshold limit value.

(c) 2018 The Authors. Published by Innovare Academic Sciences Pvt Ltd. This is an open access article under the CC BY license (http://creativecommons. org/licenses/by/4. 0/) DOI: http://dx.doi.org/10.22159/ajpcr.2018.v11i2.23160

\section{INTRODUCTION}

The Indian Pharmaceutical Industry is making enormous progress not only in the creation of excellence but also to meet the global requirements of providing APIs and quality medicines as well as getting into growing fields of research, production, and clinical trials as it is a highly regulated and R\&D-driven industry. Pharmaceutical industries also have many environmental problems, like the other chemical industries, especially in API manufacture [1,2]

Chemicals have become part of our lives to support many of our daily activities, preventing and controlling diseases, increasing agricultural productivity, and so on. Chemicals used as synthetic drugs being at the core of modern industrial and production systems, the risk of accidents involving chemicals has attained a very serious concern for hazards management within the government, corporate sector, and the community at large. Major chemical (industrial) hazards are low in frequency but are significant in terms of potential loss of lives, injuries, environmental impacts, property damage, and socioeconomic implications. The frequency and severity of chemical hazards have increased in recent years due to the rapid development of the largest chemical industries - production and formulation, petrochemicals, pharmaceuticals, agrochemicals, industrial chemicals, and hazardous chemicals - oil deposits, exploration/extraction and reclamation sites, and so on. Increasing the size of plants, deposits, and bearers, especially in densely populated areas, represented the greatest risk and vulnerability to these dangers [3]

Hazard is a situation that poses a threat to life, health, property, or the environment. Industrial hazard can be defined as any condition produced by industries that can cause injury or death to personnel or loss of product or property [4].

Hazardous materials are chemicals that, if released or abused, can pose a threat to the environment or health. They include industrial chemicals, pesticides, agricultural chemicals, pharmaceuticals, cosmetics, and food chemicals that may be present at the workplace and "have a negative effect on a worker's health as a result of direct contact or exposure to the chemical substance." The first and fundamental step leading to the safe use of chemicals is knowledge of their identity, their health and environmental risks, and the means to control them. This knowledge must be available with an affordable cost and effort. In addition, this intrinsically complex knowledge must be organized in such a way that key information on relevant risks and protection measures can be identified and transmitted to the user in an easy-to-understand manner [5].

The main aim of this article is to provide a brief and comprehensive review of chemical hazards encountered by the pharmaceutical industry including the types of chemical hazards, their management and regulation in India.

\section{GENERAL TERMINOLOGY USED WHILE DISCUSSING HAZARDS}

1. Hazard is a term associated with a substance that could cause injury in a particular environment or situation. The hazard of a substance depends on:

- Its toxicity: How it is absorbed, metabolized, and excreted, how it acts quickly and its warning symptoms. If the toxicity of a substance is greater, it will be more toxic.

- Its physical characteristics: The way a substance will be found in the workplace. For example, a high-pressure steam liquid will reach a higher concentration in the air and will be more hazardous than an equally hazardous liquid with lower vapor pressure.

2. Industrial hazard may be defined as any condition produced by industries that may cause injury or death to personnel or loss of product or property.

3. Safety in simple terms means freedom from the occurrence of any risk, injury, or loss.

4. Industrial safety or worker safety refers to the protection of workers against the risk of industrial accidents.

5. Toxicity is the ability of a substance to cause damage to the biological tissue [4]. 
6. A chemical is any element, chemical compound, or mixture of elements and/or compounds.

- Element - the simplest form of matter that cannot be further subdivided by chemical substances. Examples of elements are aluminum, carbon, chlorine, hydrogen, mercury, and oxygen.

- Chemical compound - A substance consisting of two or more elements combined or linked so that their constituent elements are always present in the same proportions.

- Mixture - any combination of two or more chemicals if the combination is not, in whole or in part, the result of a chemical reaction (occupational safety and health administration [OSHA], 2007).

7. Chemical hazards can be defined as those where potentially hazardous energy is released through the breakdown of the molecular bond as a result of a chemical reaction (usually a reactive chemical hazard).

8. On the other hand, toxic chemicals are defined in terms of effect; for example, The National Transport Commission has defined toxic chemicals as "substances that can cause death or serious injury or damage to human health if ingested or inhaled or in contact with the skin."

9. Hazardous substances can be defined in operational mode such as "those that, after the exposure have negative effects on worker's health [6]."

\section{ROUTES OF EXPOSURE TO CHEMICALS}

To cause health problems, chemicals must get entry in the body. There are five main "forms of exposure" or ways in which a chemical can enter the body:

\section{Inhalation}

Hazardous chemicals in the air may be inhaled and may cause damage to the body.

\section{Skin contact}

Some hazardous chemicals may damage the skin directly or may be absorbed into the body through the skin.

\section{Eye contact}

Contact with some hazardous chemicals may cause serious eye injuries.

\section{Ingestion}

Hazardous chemical products may enter the body while eating or drinking food contaminated by chemicals.

\section{Injection}

Sharp objects can puncture the skin and inject chemicals or viruses into the body [7].

\section{HEALTH EFFECTS CAUSED BY CHEMICAL PRODUCTS}

The effects of toxic chemicals on the body can be categorized as acute or chronic.

\section{Acute (short-term) effects}

Appears immediately or soon after chemical exposure. They can be minor, such as irritation of the nose or throat, or can be severe, such as eye damage or chemical vapors. The only thing that is common with these effects is that they happen instantly.

\section{Chronic (long-term) effects}

They are usually caused by continuous or long-term exposure to harmful substances. These effects are generally irreversible.

Some chemicals can cause both acute and chronic effects. For example, solvents vapor inhalation may cause immediate dizziness (acute effect). However, breathing the same vapors all the time for many years could cause liver damage (chronic effect) [8].
Some clinical symptoms of the affected organs with the relative hazard causing agents are enlisted in the Table $1[4,8]$.

\section{SOURCES OF CHEMICAL HAZARDS}

The production and use of chemicals are fundamental factors in the economic development of all countries, whether they are industrialized or developing. In one way or another, chemicals affect directly or indirectly to all humans and are essentials to our feeding (fertilizers, pesticides, food additives, packing), our health care (pharmaceuticals, cleaning materials), or our well-being (appliances, fuels). Some of the chemicals could be hazardous [9]

Chemical hazards are toxic, corrosive, irritant, carcinogenic, flammable, and mutagenic. Workplace hazardous materials information classification of chemical hazards is represented in Table 2 [9].

\section{THE HAZARDS OF ORGANIC SYNTHESIS}

Organic chemical synthesis presents industrial hazards of three main types:

- First, the active agents used to attack and modify the structure of organic compounds are, by their very nature, exceptionally able to attack and modify the organic compounds of the human body, thus producing highly poisonous effects.

- Second, the intermediate compounds in most organic synthesis are often characterized by the readiness with which they enter into chemical combination with other organic matter; they are active. This often confers toxic properties of great variety on them.

- Third, the final products, though they are medicines designed to be introduced into the human body, may nevertheless produce severe poisoning under conditions of industrial exposure [10].

Some common hazards of organic synthesis with their examples, the hazards they cause, and their management are summarized in Table 3 [10]

\section{ORGANIC SOLVENT HAZARD}

A large number of organic compounds, namely, alcohols (e.g. methanol, ethanol); ketones (e.g. acetone); aromatic compounds (e.g. benzene, toluene); nitrates and halogenated hydrocarbons; and many others are widely used as solvents in both laboratories and chemical industries.

Organic solvents are used in chemical laboratories for synthesis, extraction, separation, purification and drying, analytical methods, spectrometric and physicochemical measurements. In chemical industries, they are widely used to dissolve and disperse fats, oils, waxes, pigments, paints, rubber, and so on. They are also used as antifreeze, degreasing, and cleaning agents; as volatile organic liquids that easily evaporate at normal temperature and pressure, produce volatile organic compound emissions. For example, trichloroethylene is most commonly used as a degreasing agent for metal parts in the industry and its use at work is linked to an increased risk of developing Parkinson's disease six times.

Characteristics of organic solvents that determine the type of danger:

- Spills and solvent leakage cause significant air, soil, and water pollution.

- Inhalational exposure of volatile organic solvents and an easy absorption through the skin are the two most important ways of exposure to the workplace. For example, solvents such as dimethylsulfoxide and glycol ethers, which have water and lipid solubility, are well absorbed through the skin.

- Many organic solvents have low flammability points and burn when they light up. The flammability and explosiveness of a solvent are decisive determinants of the risk associated with its use, for example, nitrocellulose.

Classification is used to qualify the flammability hazard associated with a solvent: 
Table 1: Clinical symptoms in affected body part and their causative chemicals

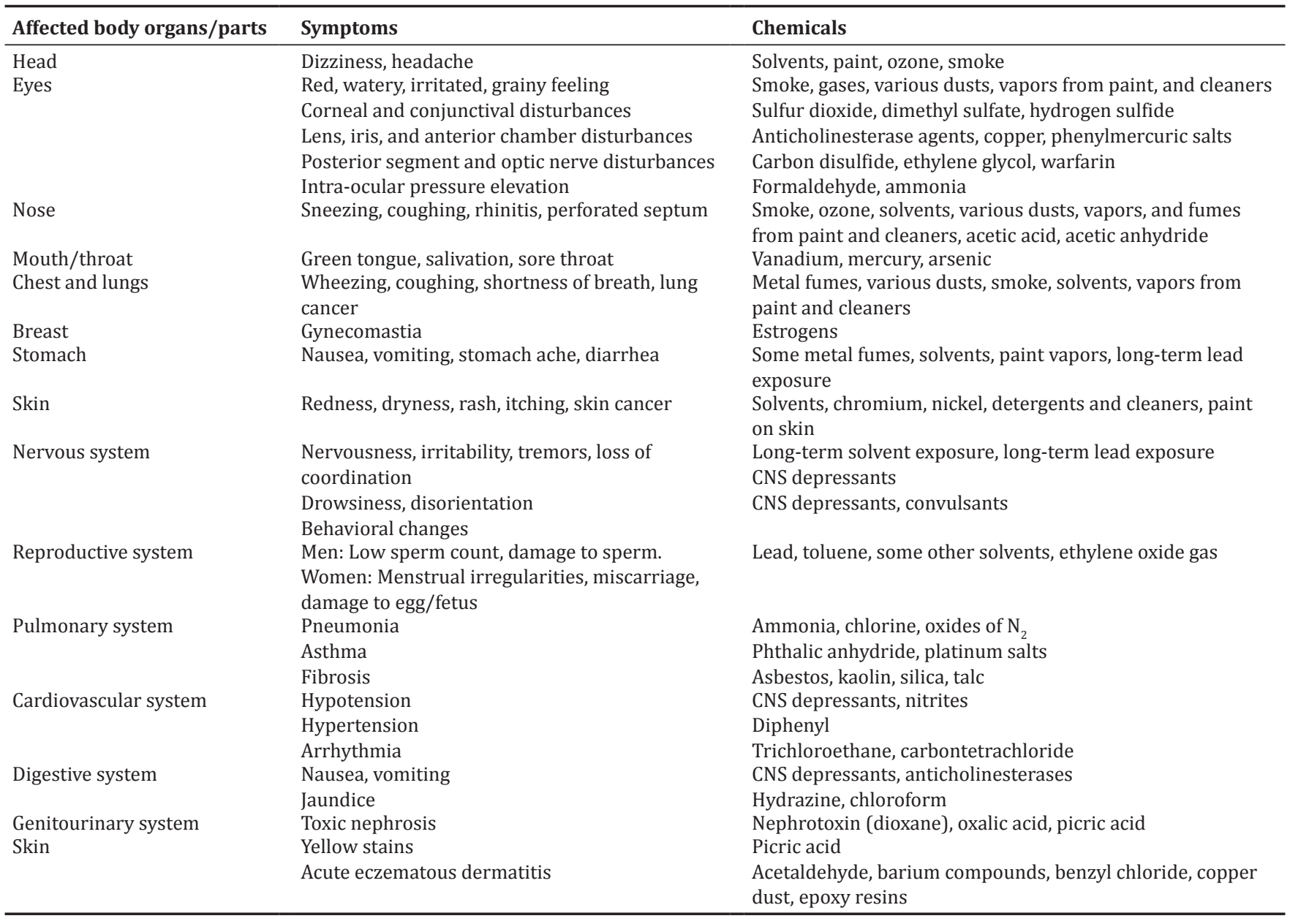

Table 2: WHMIS classification of chemical hazards

\begin{tabular}{ll}
\hline Class & Examples \\
\hline Class A & $\begin{array}{l}\text { Compressed gas } \\
\text { Dissolved gas or liquefied gas } \\
\text { Class B }\end{array}$ \\
& $\begin{array}{l}\text { Flammable gases } \\
\text { Flammable and combustible liquids } \\
\text { Flammable solids } \\
\text { Flammable aerosols }\end{array}$ \\
Class C & $\begin{array}{l}\text { Reactive flammable material } \\
\text { Oxidizing materials - oxidizer and organic peroxide } \\
\text { Oxidizer: Chlorates, nitric oxide, peroxides, } \\
\text { permanganates, per chlorates, nitrites, nitrates, easily } \\
\text { oxidize metal powder } \\
\text { Organic peroxide: Tetrahydrofuran, diethyl ether, dioxane, } \\
\text { methyl isobutyl ether }\end{array}$ \\
Class D & $\begin{array}{l}\text { Poisonous and infectious materials: cyanides, tea salts, } \\
\text { asbestos } \\
\text { Corrosive materials: Inorganic acids and bases, hydrogen } \\
\text { fluoride } \\
\text { Dangerous reactive materials: Ethylene dioxide, organic } \\
\text { azides, Na, Li, Ca } \\
\text { Class F } \\
\text { aluminum chloride, lithium }\end{array}$ \\
\hline WHMI: Workplace hazardous materials information,
\end{tabular}

- Highly flammable: Flashpoint $23^{\circ} \mathrm{C}$.

- Flammable: Flammability point $23-61^{\circ} \mathrm{C}$

- Combustible: Flammability point $61-150^{\circ} \mathrm{C}[11]$.
Carcinogenic classification of solvents by the international agency for research on cancer is presented in Table 4 [12].

\section{HAZARDOUS GASES}

Various volatile and flammable liquids used in the chemical industry, vaporize when exposed to room temperature or above, causing atmospheric pollution. The steam turns on causing fire accidents and explosions which tend to spread rapidly in the surrounding environment, causing loss of lives and property. Therefore, the storage and handling of these hazardous gases require special attention to avoid risks [13].

These can be classified as follows:

\section{Combustible gas}

Includes gases such as methane $\left(\mathrm{CH}_{4}\right)$, pentane $\left(\mathrm{C}_{5} \mathrm{H}_{12}\right)$, propane $\left(\mathrm{C}_{3} \mathrm{H}_{8}\right)$, butane $\left(\mathrm{C}_{4} \mathrm{H}_{10}\right)$, and hydrogen $\left(\mathrm{H}_{2}\right)$ when released in an installation naturally as a by-product or leaked, gets ignited when comes in contact with oxygen. This represents the danger of combustion within a facility if the concentration reaches a certain optimum level. Fuel gas detectors are needed when there is a risk of life or property due to the accumulation of combustible gases.

Each type of fuel gas has three important ranges, and each of these ranges differs for specific gases but uses the same definitions.

- Fuel gas concentration is too low for combustion below the lower explosion limit (LEL) or lower flammable limit. This is the range in which more fuel gas detectors work.

- The upper explosive limit (UEL) or upper flammability limit is the 
Table 3: Common hazards of organic synthesis with examples, causes, and management

\begin{tabular}{|c|c|c|c|c|}
\hline S. No. & Hazard causing agents & Examples & Hazards caused & Hazards management \\
\hline 1 & Chlorinating agents & $\begin{array}{l}\text { Chlorine, phosgene }\left(\mathrm{COCl}_{2}\right) \text { (gases), } \\
\left.\text { Phosphorus oxychloride ( } \mathrm{POCl}_{5}\right) \text {, } \\
\text { thionyl chloride }\left(\mathrm{SOCl}_{2}\right) \text { [liquids], } \\
\text { Phosphorus } \\
\text { pentachloride }\left(\mathrm{PCl}_{5}\right) \text { [solid]. }\end{array}$ & $\begin{array}{l}\text { Lung irritants; may produce } \\
\text { pulmonary edema if inhaled in } \\
\text { sufficient amounts. } \\
\text { In addition to being poisons, they } \\
\text { are highly corrosive to common } \\
\text { metals. }\end{array}$ & $\begin{array}{l}\text { The workers should be } \\
\text { equipped with air-supply } \\
\text { masks or closed oxygen } \\
\text { systems. }\end{array}$ \\
\hline \multirow[t]{2}{*}{2} & Sulfonating Agents & $\begin{array}{l}\text { Chlorosulfonic acid }\left(\mathrm{HOSO}_{2} \mathrm{Cl}\right) \\
\text { (used in the manufacture of } \\
\text { p-acetylaminobenzene sulfonyl } \\
\text { chloride, a necessary intermediate } \\
\text { for most sulfonamides). }\end{array}$ & $\begin{array}{l}\text { The fumes of the acid are highly } \\
\text { irritating. } \\
\text { In many sulfonation reactions, HCL } \\
\text { gas and } \mathrm{SO}_{2} \text { are given off which may } \\
\text { lead to bronchitis and conjunctivitis. } \\
\text { The heat of reaction of oleum and }\end{array}$ & $\begin{array}{l}\text { Scrubbing towers of simple } \\
\text { and cheap design, or very } \\
\text { high stacks, are usually } \\
\text { required to eliminate the } \\
\text { nuisance. } \\
\text { Liberal dousing with }\end{array}$ \\
\hline & & $\begin{array}{l}\text { Conc. } \mathrm{H}_{2} \mathrm{SO}_{4} \text { and fuming sulfuric } \\
\text { acid (oleum). }\end{array}$ & $\begin{array}{l}\text { water is so great that it requires } \\
\text { proper method for washing this } \\
\text { acid off the skin, if spilled. }\end{array}$ & $\begin{array}{l}\text { anhydrous ethyl alcohol } \\
\text { for first wash, followed } \\
\text { immediately by streams of } \\
\text { water. }\end{array}$ \\
\hline \multirow[t]{2}{*}{3} & Methylating agents & Dimethyl sulfate $\left[\left(\mathrm{CH}_{3}\right)_{2} \mathrm{SO}_{4}\right]$. & $\begin{array}{l}\text { It is a highly corrosive, volatile } \\
\text { liquid with vesicant and } \\
\text { lung-irritant properties. }\end{array}$ & $\begin{array}{l}\text { It must be handled with the } \\
\text { care. }\end{array}$ \\
\hline & & Diazomethane. & $\begin{array}{l}\text { It is an extremely poisonous, yellow, } \\
\text { odorless gas. Results in red, itching } \\
\text { areas and blisters on the skin. } \\
\text { Inhalation causes severe bronchial } \\
\text { catarrh and disturbance of eye } \\
\text { accommodation. }\end{array}$ & $\begin{array}{l}\text { Closed system, ventilation, } \\
\text { explosion-proof electrical } \\
\text { equipment and lighting. } \\
\text { Use protective gloves and } \\
\text { clothing. }\end{array}$ \\
\hline 4 & Acetylating Agents & $\begin{array}{l}\text { Glacial acetic acid, acetic anhydride, } \\
\text { monochloroacetic acid, and } \\
\text { dichloroacetic acids. }\end{array}$ & $\begin{array}{l}\text { Results in extensive desquamation } \\
\text { of the skin, especially on the palms } \\
\text { and are also categorized as lung } \\
\text { irritants. }\end{array}$ & $\begin{array}{l}\text { If spilled, soak the affected } \\
\text { parts for } 4 \mathrm{~h} \text { in } \mathrm{NaHCO}_{3} \\
\text { solution to prevent the } \\
\text { damage as it permit the } \\
\text { reagent to diffuse out of the } \\
\text { skin. }\end{array}$ \\
\hline
\end{tabular}

Table 4: Classification of solvents on the basis of carcinogenicity by the international agency for research on cancer

\begin{tabular}{ll}
\hline Group & Description \\
\hline Group 1 & $\begin{array}{l}\text { Carcinogenic to humans, which are based mainly on } \\
\text { studies in humans, e.g.: Benzene (recognized human } \\
\text { carcinogen) as it is associated with certain forms of } \\
\text { Leukemia in heavily exposed workers }\end{array}$ \\
Group 2A & $\begin{array}{l}\text { Probably carcinogenic to humans, based on sufficient } \\
\text { evidence from animal studies, e.g.: Tetrachloroethylene, }\end{array}$ \\
& $\begin{array}{l}\text { TCE, acrylamide, benzidine-based dyes, diethyl sulfate, } \\
\text { and formaldehyde }\end{array}$ \\
Group 2B & $\begin{array}{l}\text { Possibly carcinogenic to humans, based on a } \\
\text { combination of effects in humans, animals and other } \\
\text { evidence. e.g.: Dichloromethane, ethyl acrylate, } \\
\text { tetrachloroethylene, chloroform, acetaldehyde, styrene } \\
\text { Not classifiable as to its carcinogenicity to humans due } \\
\text { to limitations in the dataset } \\
\text { Proup 3 } \\
\text { Group 4 } \\
\text { combination of effects in epidemiologic and animal } \\
\text { studies together with other evidence }\end{array}$ \\
\hline TCE: Trichloroethylene
\end{tabular}

point where the gas concentration is too rich for combustion, or the oxygen level is too low to support combustion.

- Between LEL and UEL, concentration (measured as a percentage of air volume) supports combustion of combustible gas when exposed to a source of ignition. The flammability of many gases is in a very limited and concentrated range [14].

\section{Toxic gases}

Toxic gases produce an immediate and persistent hazard to human resources and include gases such as carbon monoxide, chlorine, nitrogen oxide, sulfur dioxide, hydrogen chloride, hydrogen cyanide, ammonia, hydrogen fluoride and many others. They are usually hazardous even at low concentrations and are often characterized in terms of threshold limit value (TLV) [15].

\section{Oxygen deficiency}

In many common working environments, there is the potential for low oxygen atmospheres due to the gas cylinder and cryogenic exposure. Cryogenic freezing uses $\mathrm{CO}_{2}$ or liquid $\mathrm{N}_{2}$. Argon is used in inert welding processes. Environmental chambers and test cells inject liquid nitrogen or use heat exchangers for rapid cooling. Hydrogen is widely used in research for alternative fuel vehicles. Liquid helium cools superconducting magnets for research and medical imagings such as magnetic resonance imaging machines. Oxygen depletion can be caused by any of the following processes such as displacement, combustion, oxidation, chemical reaction, or bacterial action.

Cryogenic liquids have huge expansion ratios (460-840 to 1 for those listed), so a big gas cloud is likely to occur for a little amount of cryogenic liquid. Continuous monitoring with risk mitigation measures must be used to ensure the safety of personnel working in the field of gas use or storage. When stationary gas detection is positioned, it is useful to include hazardous gases dynamics such as ventilation, stratification or the possible diffusion and gas features. Simple smoke tests can reveal the essential characteristics of the airflow of the area and greatly simplify the positioning of the gas 
detection. Mount the sensors in the breathing zone (4-6 feet above the level) to protect the staff.

When the oxygen concentration drops, suffocation occurs. OSHA established $19.5 \%$ oxygen in the air as the lower limit of a safe environment $[15,16]$.

\section{Gas Sensor placement}

- Place the sensors near a possible source of gas.

- Place the sensors in the areas where the gas accumulates.

- Insert oxygen and toxic gas exhaust sensors into the "respiratory zone."

- Consider accessibility and maintenance issues [13].

\section{Hazardous gas management}

Compressed gases are filled in cylinders and transported to the place of use. Important precautions to be taken include the following:

1. The cylinders must not be released or allowed to hit the other.

2. The safety devices installed on the cylinders must not be tampered with.

3. Use special valves and standard tools. Normally, these are supplied by the manufacturers.

4. The cylinders must be protected against extremes of weather, especially against excessive rise in the temperature.

5. The cylinders (receipts) must bear a standard label indicating the type of gas. The color of the label indicates whether the gas is flammable, corrosive, or inert.

6. Full cylinders must be separated from the empty ones $[4,13]$.

\section{Components of a gas hazard management system}

A gas monitoring system should provide information to ensure that effective and complete decisions are made promptly. To be more effective in the management of gas exposure risks, sufficient information is needed to obtain a thorough assessment of the situation to make good decisions. Data management is a key element of a gas hazard management system.

Risk assessment

It is the first step in system design. Field studies can help determine when and where are the hazardous situation and possible exposure. The hazard characteristics can be determined in terms of ignition, reactivity, corrosivity, and toxicity. The risk to human health is reflected in the standards set by the resource conservation and recovery act, OSHA and environmental protection agency (EPA). The information obtained in a risk assessment provides a basis for better addressing the risk of identified gas.

System specifications and designs

It is the key outcome of the risk management planning process. The design begins with the selection and position of the sensor type. Sensor performance should be determined in terms of response speeds, concentration range, and resolution drift, ease of calibration and interference gas and must meet the performance criteria set out in the plan.

Daily operation

The daily operation of a gas monitoring system focuses on data revision procedures and system reliability. Automatic self-diagnosis of unit functions improves reliability by providing a continuous indication of the operation. Regular maintenance should confirm the internal diagnosis.

\section{Alarm response}

The alarm response starts with the previous schedule: In the system and outside the perimeter of the system. Training is essential to ensure that all staff in the headquarters understand their role and have internalized their responsibilities. Training includes the identification of false alarms. Relay action usually involves a low alarm (warning light and siren and ventilation for gas concentration dilution) and a high alarm (emergency and siren light and process action). The action of the process involves stopping or isolating the gas source and stopping the process equipment.

Recording

It is an important element of the alarm response. The sensor status reports provide a valuable reference to assess the severity and magnitude of the gas hazard. It can generate real-time and post-event analysis. It is the transfer of information provided by the system to the staff of the plant, which enables effective gas risk management [15].

\section{CONCENTRATIONS PERMITTED IN THE AIR}

Employers should identify and assess the respiratory risks in their workplaces. Several types of occupational exposure limits (OELs) have been established by several organizations and are listed in many of the OSHAs Guidelines for Chemical and Toxic Substances. A brief explanation of some of the different levels is listed in Table 5 [17].

\section{Common terminology used in discussing OELs includes Level of action}

An airborne level, typically half the permissible exposure limits designated in the OSHA substance-specific standards, 29 CFR 1910, subheading Z, calculated as an 8-h weighted average, which initiates some necessary activities such as exposure monitoring and medical surveillance.

\section{Ceiling limit}

The exposure limit that a worker's exposure may never exceed.

\section{Sampling and analytical error}

A statistical estimate of the uncertainty associated with a given exposure measurement.

\section{Short-term exposure limit (STEL)}

The average exposure to a contaminant to which a worker can be exposed for a short period of time (typically 15-30 min).

\section{Time-weighted Average (TWA)}

Average exposure to a pollutant in a given period of time, typically $8 \mathrm{~h} \mathrm{[17].}$

\section{TLV CONCEPT}

A list of threshold limits (TLV) for about 800 substances has been prepared. Workers should not be exposed to substances beyond these limits. The following three TLV categories are specified:

\section{TLV-time weighted average (TWA)}

The TWA for concentration for a normal daily work of $8 \mathrm{~h}$ and $40 \mathrm{~h}$ work/week, to which almost all workers can be exposed several times day after day with no adverse effects.

\section{TLV-STEL}

Defined as a weighted average of $15 \mathrm{~min}$, this must not be exceeded at any time during a working day, even if the weighted average of $8 \mathrm{~h}$ is within the TLV. This is the highest concentration where staff can be exposed for short periods of time without expressing symptoms of irritation, chronic or irreversible tissue damage or narcosis sufficiently to increase the risk of accident or essentially reduced efficiency of work.

\section{TLV-ceiling}

The concentration that must not be exceeded during any part of the working day.

Numerical TLV values do not take into account the toxicity that may result from skin absorption. It should be emphasized that TLVs are 
Table 5: List of OELs established by different organisations

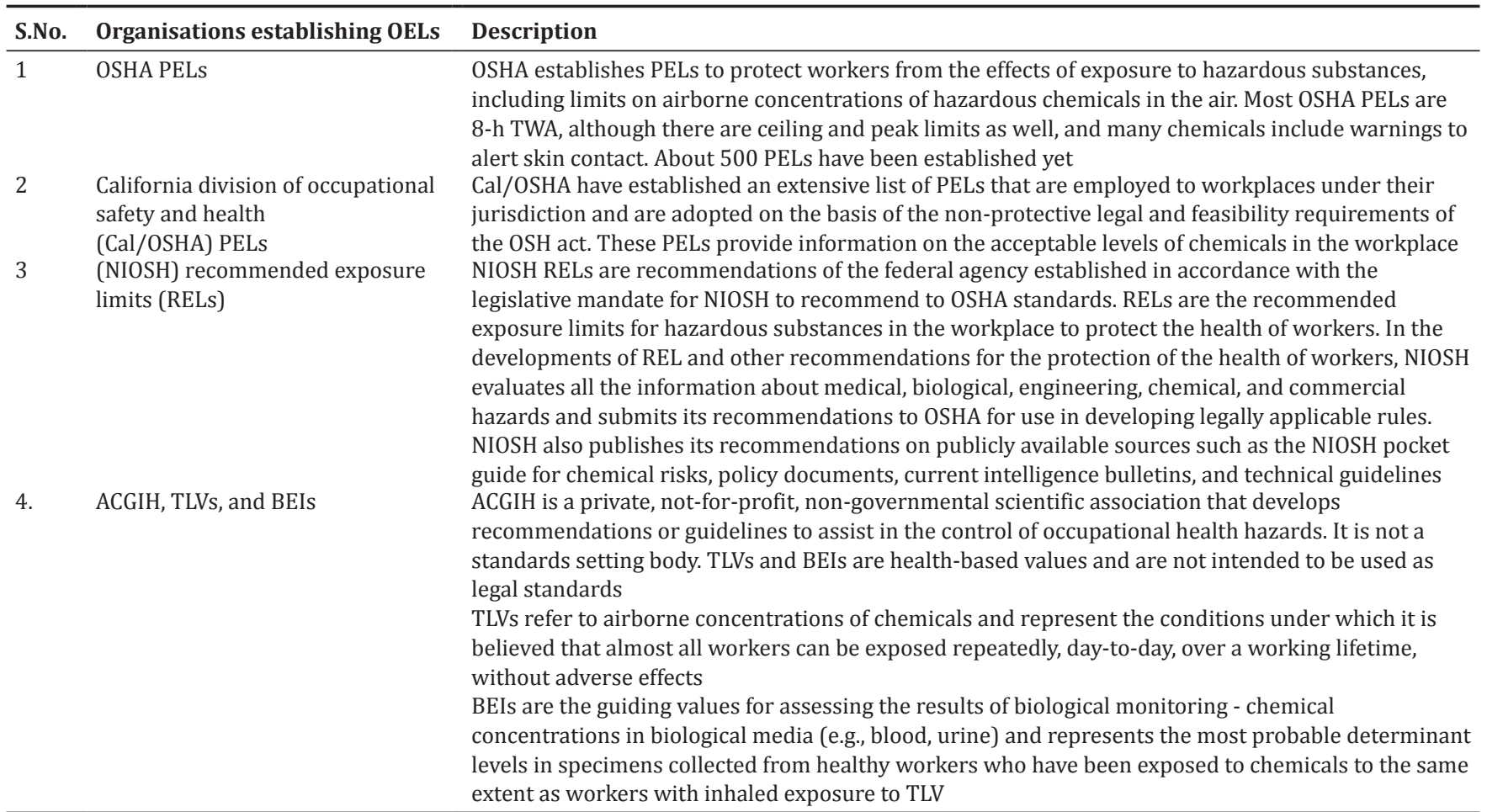

PELs: Permissible exposure limits, TWA: Time weighted average, OELs: Occupational exposure limits, TLVs: Threshold limit values, OSHA: Occupational safety and health administration, BEIs: Biological exposure indices, ACGIH: American Conference of Governmental Industrial Hygienists

only guidelines and are not intended to be absolute limits between safe and hazardous concentrations. Every occupational health professional must have a copy of the current TLVs and biological exposure indices $[4,13]$.

\section{CHEMICAL HAZARD CONTROL: TECHNICAL MEASURES}

Technical measures that can be used to prevent chemical dangers at the source and/or reduce staff exposure:

\section{Substitution}

It is an effective control method. A hazardous chemical substance is replaced by a less hazardous thing. It is particularly preferable if highly hazardous substances, such as carcinogens, can severely affect human physiological systems. However, it must be ensured that the substitution substance eliminates the danger of the above substance.

\section{Engineering control (closed system)}

In the absence of effective replacement, personnel must be safeguarded against any exposure. Steam and gas exposures should also be monitored and minimized if risks are involved in their use. A generally effective measure is to encircle the hazardous process or chemical. For example, sealed pipes should be used to transfer toxic or highly flammable solvents and other liquids (especially volatile) rather than pouring them outdoors.

\section{Local ventilation systems}

If it is not possible to isolate experimental activities involving hazardous materials, then a properly designed local ventilation solution should be found, which generally helps remove contaminants at the source. A ventilation system consists of a hood, duct or pipe drain, a collecting system and contaminants are separated from clean and efficient air to create the fan suction force required. However, hazardous gases, fumes, and dusts from the ventilated air collection must be handled or treated before disposal. Inspection, proper maintenance, regular cleaning, and changing filters are essential for the protection against hazardous pollutants.

\section{General ventilation}

When it is difficult or impossible to avoid hazardous chemicals, fumes, dusts, fogs, or particles entering the laboratory air at the source, general dilution ventilation can be installed so that the maximum concentration of pollutants in the air does not exceed the TLV of the substance. At the best, it should consist of a clean air supply and a forced exhaust outlet in the right place. It can also be used in conjunction with other preventative measures.

\section{Housekeeping}

When working with hazardous chemicals, proper maintenance is required. The storage/stack/cabinet areas should be well organized and kept in order and along with the maintenance of premises and equipment should be planned. These tasks should be dedicated to individuals/laboratory workgroups. In addition, periodically check and repair the defective equipment. Cleaning efficiency should be monitored with adequate periodicity; this should involve the professors in charge/students/staff associated with a laboratory [18].

\section{MAINTENANCE OF OVEREXPOSURE TO CHEMICALS}

Although thousands of chemicals are commonly used in industry, the medical management of acute overexposure is not specific and includes four basic steps (with some exceptions).

\section{Removal from exposure}

- Immediate removal of the person from the display site is the first step.

- If a disabled victim is to be rescued; the rescue workers must protect themselves from contaminated atmosphere first.

- Respirators and rescue lines are compulsory first aid.

- Sometimes chemically impervious suits are also worn.

\section{Resuscitation}

- Resuscitation means restoring the life of someone apparently dead (collapsed or shocked).

- If the victim is apneic, resuscitation should start as soon as it is removed from the area. 
- Sustainable care must be provided as with any other medical emergency.

\section{Decontamination}

- A victim whose skin or clothing has been contaminated requires immediate removal of clothing and shoes. Then, a vigorous shower with soap and water is recommended, including attention to nails and scalp.

\section{Symptomatic treatment}

- Acute overexposure can cause a series of signs and symptoms that require general medical support, regardless of the specific agent. Examples include convulsive seizure control, bronchospasm treatment, dehydration, and arrhythmias.

There are some situations where specific antidotes or management strategies are available. The industry should prepare a list of medical management strategies for hazardous chemicals that it manages so that it can take corrective action and can attempt immediate rescue $[4,13]$.

\section{WORKPLACE SAFETY}

Workplace safety is a joint responsibility of all individuals to create a healthy and safe workplace:

- Hazards of chemical substances exist and occur everywhere in the workplace. Students and professional workers must act by keeping safety in the mind all day, every day.

- Establish and clarify the rights and responsibilities of security in all workplaces.

However, it is the responsibility of the administration to:

- Educate workers and employers in the construction and maintenance of safe and healthy workplaces.

- Intervene when security responsibilities are not executed.

- Provide information and resources on a variety of security issues and to prevent injuries and workplace illnesses.

Any safety management system (SMS) is a constituent part of the overall management system of an organization/industry/establishment which reflects the overall management philosophy and system to achieve the goal. An SMS includes several important inputs such as:

- The purpose of inspections.

- Importance of workplace inspections.

- Plan of inspection.

- Types of hazards to be looked for in a workplace.

- Information needed to complete an inspection report.

- Time taken for an inspection.

- Frequency of inspections.

- The periodic audits, with routine monitoring of performance, should be carried out to determine the overall performance of the
SMS in confirmation to requirements. The results are used to make necessary improvements for meaningful implementation of the work.

- The SMS requires periodic critical inspection of both workplace and workers to control and prevent the possible occurrences of injuries, accidents, and related problems for the necessary corrective action.

- Periodical workplace inspection by a qualified inspection team to know the real problems, if any, of the workers and workplace managers/supervisors. This help to identify jobs and tasks of the workers, the potential hazards that the workers are exposed to, and the possible reasons for occurrences of hazards [19]

\section{REGULATIONS FOR CHEMICAL HAZARDS}

The chemical management relies on a mix of national, regional, and international mechanisms, a range of multilateral environmental agreement, as well as voluntary initiatives including a globally harmonized system of classification and labeling of chemicals, the strategic approach to international chemicals management and responsible care. In many countries, legislative and administrative measures have been introduced to deal with chemical hazards.

In 1992, the United Nations Conference on Environment and Development (the Rio Earth Conference) gave rise to the Agenda 21 Report 2. This report outlined the responsibilities of States toward the achievement of sustainable development and was adopted by heads of Government in over 150 countries. Chapter 19 of Agenda 21 addresses the environmentally sound management of toxic chemicals for all countries, including basic programs for:

1. Adequate legislation.

2. Information gathering and dissemination.

3. Capacity for risk assessment and interpretation.

4. Establishment of risk management policy.

5. Capacity for implementation and enforcement.

6. Capacity for rehabilitation of contaminated sites and poisoned persons.

7. Effective education programs.

8. Capacity to respond to emergencies.

Some international treaties related to chemical management and India's participation in them is represented in Table 6 [20].

The Indian Chemical Industry is poised for growth, and a clearly defined vision has been developed to enable it. The vision for Indian chemical industry is "To facilitate the growth and development of the chemical industry in an environmental friendly manner; with focus on innovation to meet local needs, sustainability, and green technologies and processes; so as to enable it to become a globally competitive major-player."

The non-regulatory mechanisms adopted by industries in India, in addition to legislative control, play a very important role in the

Table 6: International treaties related to chemical management and India's participation

\begin{tabular}{|c|c|c|}
\hline S. No. & International treaties related to chemical management & Responsible government agencies in India \\
\hline 1 & Agenda 21 - commission for sustainable development & $\begin{array}{l}\text { Ministry of external affairs, ministry of environmental, forests and climate } \\
\text { change }\end{array}$ \\
\hline 2 & UNEP London guidelines & Ministry of environmental, forests and climate change \\
\hline 3 & FAO code of conduct & $\begin{array}{l}\text { Ministry of agriculture, ministry of environmental, forests and climate } \\
\text { change }\end{array}$ \\
\hline 4 & $\begin{array}{l}\text { The Rotterdam convention - PIC procedure for certain } \\
\text { hazardous chemicals and pesticides in international trade }\end{array}$ & $\begin{array}{l}\text { Ministry of chemicals and fertilizers, ministry of agriculture, ministry of } \\
\text { environmental, forests and climate change }\end{array}$ \\
\hline 5 & Montreal protocol & Ministry of environmental, forests and climate change \\
\hline 6 & ILO 170 & Ministry of labour \\
\hline 7 & Basel convention & Ministry of environmental, forests and climate change \\
\hline 8 & London convention (Stockholm dumping guidelines) & $\begin{array}{l}\text { Ministry of shipping, road transport and highways, ministry of } \\
\text { environmental, forests and climate change }\end{array}$ \\
\hline 9 & Chemical weapon convention & Cabinet secretariat \\
\hline 10 & Stockholm convention on POPs & Ministry of environmental, forests and climate change \\
\hline 11 & Bilateral Agreements & Indo-GTZ project, ministry of environmental, forests and climate change \\
\hline
\end{tabular}


management of chemicals. Indian industries take several initiatives for environmental protection and chemical management, such as responsible care, corporate responsibility in environmental planning, ISO 14001, OHSAS 18001, ISI Marking (Indian Standards Institution), and eco-mark. Several awards related to chemical and environmental management are initiated on voluntary basis by industrial associations, who play an important role in encouraging industries to go for non-regulatory mechanisms for chemical management. Important industrial associations include Indian Chemical Council (formerly, the - Indian Chemical Manufacturer's Association), Confederation of Indian Industry, and Federation of Indian Chambers of Commerce and Industry [20].

\section{GLOBAL REGULATORY AGENCIES}

These are specially related to chemicals, drugs, and petrochemicals are many and in brief include the following (besides many more):

- US Food and Drug Administration.

- US EPA.

- Insecticides Act, 1968. Ministry of Agriculture and Cooperation, Government of India, and the Environment Protection Act, 1986, India.

- Pest Management Regulatory Agency (PMRA), Health Canada.

- PMRA, U.S. EPA.

- Federal Insecticide, Fungicide, and Rodenticide Act (FIFRA), United States.

- National Toxicology Program, United States.

- National Administration of Drugs, Food, and Medical Technology, Argentina.

- The European Agency for the Evaluation of Medicinal Products.

- Federal Institute for Drugs and Medical Devices, Germany.

- Medicines and Healthcare Products Regulatory Agency, United Kingdom.

- World Health Organization (WHO), Geneva, Switzerland.

- International Conference on Harmonization, Geneva, Switzerland.

\section{INDIAN REGULATORY AGENCIES}

The Republic of India enacted several legislations, rules, and regulations to exercise all the powers vested under the Act and Rules pertaining to the protection of environment and control of pollution. These are implemented and enforced in all environment legislation agency activities. The selected acts and Regulations include, but are not limited to, the following:

- $\quad$ Drugs and cosmetics act, 1940.

- The prevention of food adulteration act, 1954.

- Insecticides act, 1968.

- The water (prevention and control of pollution) act, 1974.

- Air (prevention and control of pollution) act, 1981.

- Narcotic drugs and psychotropic substances act 1985

- The environment (protection) act, 1986.

- Manufacture, storage, and import of hazardous chemicals rules, 1989.

- Hazardous wastes (management and handling) rules, 1989.

- Water prevention and control of pollution act, 1974.

- Hazardous waste (management and handling) rules, 1989.

- Manufacture, storage and import of hazardous chemical rules, 1989.

- Rules for manufacture, use, import and storage of hazardous microorganisms, genetically engineered micro-organism or cells, 1989.

- Biomedical waste (management and handling) rules, 1998.

- The recycled plastic manufacture and usage rules, 1999.

- The ozone-depleting substances (regulation and control) rules, 2000.

- The noise pollution (regulation and control) rules, 2000.

- $\quad$ The batteries (management and handling) rules, 2001 [19].

Our quality of life has significantly improved through chemistry since it has provided us with various useful products, but this has also provoked global environmental deprivation and the decline of non-renewable natural resources. Many pollutants end their path to the food chain and deteriorate the ecosystem. Green chemistry and its principles can change all of these negative aspects and impacts and through design, innovation, and green practices to restore the sustainable development. The ultimate goal is to develop and design non-conventional synthetic methodologies for important industrial chemicals to prevent/reduce environmental pollution [21].

\section{CONFLICT OF INTEREST: None}

\section{AUTHOR CONTRIBUTION}

Princy Agarwal: Conceptualization of work, wrote the manuscript, compilation of literature sources.

Rajat Vaishnav: Wrote the parts of the manuscript, checked the manuscript and references and contributed in enhancing the standard of the manuscript.

Anju Goyal: Reviewing and checking of the manuscript and contributed in enhancing the standard of the manuscript.

\section{REFERENCES}

1. Dubey R. Hazard Management in Pharmaceutical Industry. Event Report and Material. Bhopal: Disaster Management Institute, Sponsored by Disaster Management Institute, Bhopal and GIZAdvisory Service for Environmental Management (Cooperating Partner); 2010. Available from: http://www.hrdp-idrm.in/live/ hrdpmp/hrdpmaster/idrm/content/e6547/e6546/e10804/e11995/ eventReport12000/BackgroundPaperonHazardManagement.pdf. [Last cited on 2017 Oct 11].

2. Shabaninejad H, Madani H, Amineh ZA, Doostzadeh E. A framework for evaluation of pharmaceutical industry development in developing countries: Evidence from Iran. Asian J Pharm Clin Res 2016;9:50-4. Available from: https://www.innovareacademics.in/journals/index.php/ ajpcr/article/view/10099/7527. [Last cited on 2017 Nov 11].

3. Gupta AK, Nair SS. Chemical (industrial) Disaster Management, Trainer's Module. New Delhi: National Institute of Disaster Management (Ministry of Home Affairs); 2012. Available from: http://www.nidm.gov.in/PDF/modules/chemical.pdf. [Last cited on 2017 Oct 11].

4. Subrahmanyam CV. Pharmaceutical Production and Management. $1^{\text {st }}$ ed. Delhi: Vallabh Prakashan; 2015.

5. Hazard Guidelines-Hazardous Material Spill. Ann Arbor: University of Michigan, Division of Public Safety and Security; 2011. Available from: http://www.dpss.umich.edu/docs/HazardGuidelinesHazardousMaterialSpill.pdf. [Last cited on 2017 Oct 11]

6. Pisaniello D, Tepe S. Chemical Hazards. In: HaSPA (Health and Safety Professionals Alliance), The Core Body of Knowledge for Generalist OHS Professionals. Australia: Safety Institute of Australia Ltd; 2012. Available from: http://www.ohsbok.org.au/wp-content/ uploads/2013/12/17-Hazard-Chemical.pdf?x71776. [Last cited on 2017 Oct 11].

7. Canadian Centre for Occupational and Health Safety. Canada: Canadian Centre for Occupational and Health Safety (CA). Available from: https://www.ccohs.ca/products/posters/pdfs/chemical.pdf. [Last modified on 2016 Nov 30; Last cited on 2017 Oct 11].

8. Occupational Safety and Health Administration (WOSH Specialist Training Supplemental Module). Washington, DC (US): United States Department of Labor. Available from: https:/www.osha.gov/dte/ grant materials/fy11/sh-22240-11/ChemicalHazards.pdf. [Last cited on 2017 Oct 11].

9. Reddy BV, Sandeep P, Navaneetha K, Ujwala P. Review on industrial hazards and its prevention. Int J Med Pharm Res 2014;2:492-502. Available from: https://www.researchgate.net/profile/B_Reddy7/ publication/275518968 Pulsatile Drug Delivery System-A-Review/ links/553e22cc0cf294deef6fba29/Pulsatile-Drug-Delivery-System-AReview.pdf. [Last cited on 2017 Oct 11].

10. Watrous RM. Health Hazards of the Pharmaceutical Industry. Br J Ind Med 1947;4:111-25. Available from: https:/www.ncbi.nlm.nih.gov/ pmc/articles/PMC1035910/pdf/brjindmed00258-0037.pdf. [Last cited on 2017 Oct 11]

11. Pruthu K. Organic Solvents-Health Hazards. J Chem Pharm Sci 2014; special issue 3:83-6. Available from: https://www.jchps.com/ specialissues/Special\%20issue3/17\%20jchps\%20si3\%20k.pruthu $\% 20$ 83-86.pdf. [Last cited on 2017 Oct 11].

12. Chemical Engineering, IIT Bombay. Information on Carcinogenic 
Compounds. Mumbai (IN): Dept. of Chemical Engineering, IIT Bombay. Available from: http://www.che.iitb.ac.in/online/research/ health-safety-and-environment-hse/hse-plan-a-guide-laboratoryhazards-and-practices/informa. [Last cited on 2017 Oct 11].

13. Pharmaceutical Industries: Industrial Hazards. India: Blogger (Awesome Inc.); 2011. Available from: http://www.pharmaindustries.blogspot. in/2011/07/industrial-hazards.html. [Last cited on 2017 Oct 11].

14. SMC: Sierra Monitor. California (USA): Sierra Monitor Corporation; 2017. Available from: http://www.sierramonitor.com/protect/ hazardous-gas-flame/combustible-gas-detection. [Last cited on 2017 Oct 11].

15. Gas Risk Management-a Safer Approach to Monitoring for Hazardous Gases. California (USA): Sierra Monitor Corporation; Technical reprint TR002. Available from: http://www.sierramonitor.com/assets/ bltb2ed9a415adbde79/SMC\%20Technical\%20Reprint\%20-\%20 Gas\%20Risk\%20Management.PDF. [Last cited on 2017 Oct 11].

16. Sensidyne: Industrial Health and Safety Instrumentation. St. Petersburg (USA): Sensidyne, LP; c2017. Available from: https://www. sensidynegasdetection.com/support/application-support/oxygendeficiency-gas-monitoring.php. [Last cited on 2017 Oct 11]

17. Occupational Safety and HealthAdministration(Safety and health topics). Washington, DC (US): United States Department of Labor. Available from: https://www.osha.gov/SLTC/hazardoustoxicsubstances/index. html. [Last cited on 2017 Oct 11].

18. Chemical Engineering, IIT Bombay. Chemical Hazard Control: Technical Measures. Mumbai (IN): Dept. of Chemical Engineering, IIT Bombay. Available from: http://www.che.iitb.ac.in/online/research/ health-safety-and-environment-hse/hse-plan-a-guide-laboratoryhazards-and-practices/chemic-0. [Last cited on 2017 Oct 11].

19. Dikshith TS. Hazardous Chemicals: Safety Management and Global Regulations. Boca Raton, Florida (US): CRC Press (Taylor and Francis Group); c2013.

20. Balaji G, Potdar A, Unnikrishnan S. Environmental legislation for chemical management in India: An agenda. J Environ Res Dev 2014;9:494-506. Available from: https://www.google.co.in/ url?s $\quad \mathrm{a}=\mathrm{t} \& \mathrm{rct}=\mathrm{j} \& \mathrm{q}=\quad$ \&esrc$=\mathrm{s} \&$ source $=\mathrm{web} \& \mathrm{~cd}=1 \& \mathrm{cad}=\mathrm{rja}$ \&uact $=8$ \&ved $=0$ ahUKEwilo9P7o LWAhVFvY 8 KHWObAtUQFgg 1MAA\&url=http\%3A\%2F\%2F www.jerad.org\%2Fppapers\%2Fdnload. php \%3Fvl\%3D9\%26is\%3D2\%26 \%3 D494\&usg=AOvVaw19Ep1B IyXYIogsslQidkqi. [Last cited on 2017 Oct 11].

21. Bhandari M, Raj S. Practical approach to green chemistry. Int J Pharm Pharm Sci 2017:9:10-26. Available from: https:// www.innovareacademics.in/journals/index.php/ijpps/article/ view/15640/10173. [Last cited on 2017 Nov 11]. 